\title{
Study Quantum Of Transboundary Groundwater Drainage from India to Pakistan
}

\author{
Muhammad Basharat ${ }^{1 *}$ and Muhammad Jawad ${ }^{2}$ \\ ${ }^{1}$ Addl. Chief Engineer, Drainage, International Waterlogging and Salinity Research Institute (IWASRI), WAPDA, Pakistan \\ ${ }^{2}$ Department of Civil Engineer, International Waterlogging and Salinity Research Institute (IWASRI), Pakistan
}

*Corresponding author: Muhammad Basharat, Addl. Chief Engineer, Drainage, International Waterlogging and Salinity Research Institute (IWASRI), WAPDA, Pakistan.
Received Date: June 15, 2020

Published Date: June 29, 2020

\begin{abstract}
The Government of Pakistan and the Government of India were equally desirous for attaining the most complete and satisfactory utilization of the water of the Indus River System. Therefore, in a spirit of goodwill and friendship, a treaty was pledged in 1960 between these two countries, called Indus Water Treaty (IWT), 1960. According to this treaty India was given exclusive rights on three eastern rivers Ravi, Beas and Sutlej. The whole IWT deals with surface water including rivers and surface drains entering from India to Pakistan. Groundwater recharge being function of surface water were not discussed or are not the part of the treaty.The groundwater data was collected from Monitoring Organizations of both the countries and groundwater elevation contours were generated using GIS. Results revealed that the flow of groundwater has its gradient towards Pakistan in some areas and in some other areas the flow direction was found parallel to India-Pakistan Border following (NE to SW) in the direction of flow of surface water.
\end{abstract}

Keywords: Transboundary; Pakistan; India; Groundwater; Indus basin; Bari DOAB

\section{Introduction}

With IWT of 1960 between Pakistan and India, Pakistan is bound to welcome any extra surface flows and drainage effluent as being generated in India, as entering Pakistan due to natural surface drainage pattern. At the time of aforementioned treaty with India, the surface drainage water entering Pakistan was not creating any pollution issues. In contrary, nowadays the drains entering Pakistan, particularly Hudiara Drain is heavily laden with industrial, domestic and agro-chemical pollutants. Thus, with passage of time, urban, industrial and agricultural intensification ensuing to population increase across the boundary has now changed both the discharge and pollution patterns throughout the year. Also, throughout the Indian Punjab, excessive groundwater is being pumped, that too supported by electricity subsidy by the Indian government.
That is why groundwater is being depleted the highest possible rates across the borders in Indian Punjab. This has been established by international experts through GRACE studies [1], as well as Indian published research on groundwater in the area. With this developing story across the borders, the groundwater situation in Pakistani Punjab is also aggravating to various extents in different areas. However, the groundwater levels in Bari Doab are depleting excessively as compared to other Doabs in Punjab of Pakistan.

Consequently, the Pakistani water sector professionals are in a state of uncertainty that excessive groundwater level draw downs in India might also be enhancing indigenous groundwater depletion in Pakistani areas along the border, especially in Punjab. Thus, over the past half century period, both the surface water and groundwa- 
ter issues between the two countries have got new dimensions, and therefore, need to be re-evaluated for any possible legal battle with the neighbor.

\section{Indus Water Treaty [2]}

It is a water-distribution treaty between India and Pakistan, brokered by the World Bank, signed in Karachi on September 19, 1960. According to this agreement, control over the water flowing in three "Eastern Rivers", Ravi, Beas and Sutlej with the mean flow of 33 Million Acre Feet (MAF) was given to India, while control over the water flowing in three "western" rivers, Indus, Jhelum and Chenab with the mean flow of 125 MAF to Pakistan. The preamble of the treaty declares that the objectives of the treaty are recognizing rights \& obligations of each country in settlement of water use from the Indus rivers system in a spirit of goodwill, friendship and cooperation contrary to the fears of Pakistan that India could potentially create droughts and floods in Pakistan, especially at times of war, since substantial water inflows of the Indus basin rivers are generated from India. According to this treaty, Ravi, Beas and Sutlej, which constitute the eastern rivers, are allocated for exclusive use by India before they enter Pakistani area. However, a transition period of 10 years was permitted in which India was bound to supply water to Pakistan from these rivers until Pakistan was able to build the canal system for utilization of water of Jhelum, Chenab and the Indus itself, allocated exclusively to it under the treaty. Similarly, Pakistan has exclusive rights to use of the Western Rivers i.e. Jhelum, Chenab and Indus but with some stipulations for development of projects on these rivers in India. Pakistan also received one-time financial compensation for the loss of water from the Eastern Rivers. Since March 31, 1970, after the 10-year moratorium, India has secured full rights for use of the water of the three eastern rivers allocated to it.

Thus, rivers are divided, not waters, as it might be. It is very important to mention here that treaty includes only surface water transboundary distribution, but does not include any provision regarding groundwater distribution, which has become need of the hour. In 2003, J\&K State Assembly passed a unanimous resolution for the abrogation of the treaty and again in June 2016, the Jammu and Kashmir assembly demanded for revision of the IWT. The legislators feel that the treaty trampled upon the rights of the people and treats the state of Jammu and Kashmir as a non-entity.

\section{Indus Basin Irrigation System (IBIS) in Pakistan}

Pakistan's economy is largely based on its agricultural production. Water is therefore a critical resource for its sustained economic development as for most countries. In order to fully utilize the river water resources, the IBIS has emerged as the largest contiguous irrigation system in the world. The IBIS comprises of three large dams, eighty-five small dams, nineteen barrages, twelve inter-river link canals, forty-five canal commands and more than 1 million tube wells. In monetary terms, this network is the biggest infrastructure enterprise of Pakistan accounting for approximately US $\$ 300$ billion of investment. The Figure 1 shows IBIS of Pakistan.

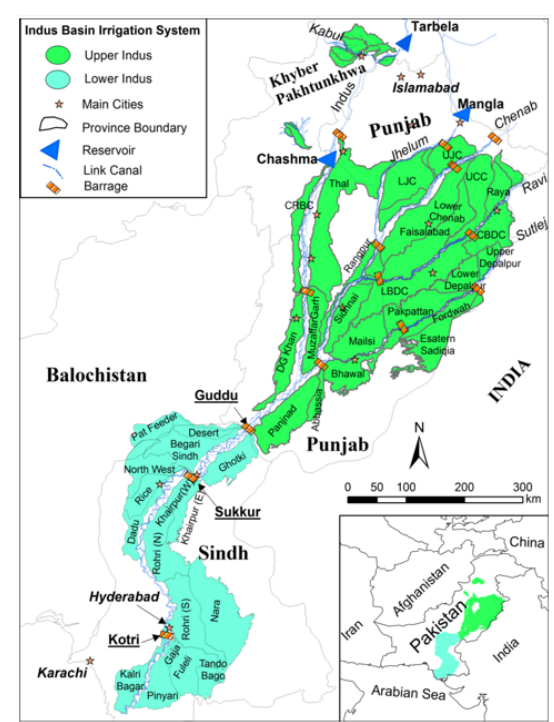

Figure 1: The IBIS System of Pakistan (Basharat, et al., 2015).

\section{Water Availability of the IBIS}

There are three main sources of water availability in the IBIS:

\section{River water}

The average annual flow of Western Rivers of Indus Basin is approximately 142 MAF. About 104 MAF of this water is diverted for irrigation purposes and about 32 MAF outflows to the Arabian Sea, the rest is un-measured in the system.

\section{Rainwater}

Another source of water is the rainfall. Irrigated areas of Indus Basin receive on average $40 \mathrm{MAF}$ water annually. Average rainfall in Pakistan is about $300 \mathrm{~mm}$ which necessitates for irrigation. 


\section{Groundwater}

The third source of water is groundwater, actually it is by-product of surface water. It provides almost 40 percent of crop water requirements of the country, at least in Punjab to the tune of $50 \%$.

\section{Challenges in IBIS}

For any sustainable irrigation system that is dependent on river water supplies, it is necessary to have a system of Effluent disposal. However, when the British engineers designed and constructed the barrages and canals in Punjab and Sindh, they did not install any affluent disposal systems. This lack of an effluent disposal system gave rise to the twin problems of waterlogging and salinity. The problem is currently being addressed through construction of a network of disposal drains, many of which have been completed while others are under execution.

After the IWT, the water of Eastern Rivers was stopped by India and the area of Bari Doab (area between Ravi and Sutlej rivers), in Pakistan suffered badly by the lack of water required for irrigation in the canal command areas fed by Eastern Rivers. So, the water is being drawn from Chenab, Indus and Jhelum to fulfill the needs of these areas through link canals and other structures. The diversion of surface water in India not only caused considerable reduction in surface water flow but also the groundwater recharge through its seepage.

\section{An Overview of Groundwater}

In Pakistan when water requirement for agriculture is not fulfilled by limited surface water resources, groundwater is used in large amounts in order to meet agriculture requirements and domestic use (fully) in most of the cities. It I s the groundwater that has contributed more than the surface water for the increased water requirements almost in every water use sector in the last 3040 years. The groundwater is a unique resource, widely available, providing security against cyclic droughts, climate change and yet closely linked to surface water resources and the hydrological cycle. Its reliable supply, good quality and suitable temperature, relative turbidity and pollution free, minimal evaporation losses, and low cost of development are the attributes making groundwater more attractive.

Although, the increased productivity obtained so far from the agriculture sector can be attributed to many factors of production along with the efficient water management e.g. building of reservoirs, improvement in surface water distribution and application etc. However, among all these improvements and innovations (water and non-water), the major chunk of contribution is the part played by the groundwater component in the form of demand-based water supply to the crops. This has been only possible due to renewable nature of the groundwater reservoir with continuous recharge from the surface.

The water stored in the aquifer can also be compared to the money kept in a current account of the bank. If you withdraw mon- ey at a faster rate than you have to recharge the account. Pumping water out of the aquifer faster than it is replenished over the longterm causes the problems. The volume of groundwater in storage is decreasing in many areas of the country in response to pumping. For example, average annual groundwater depletion in various areas of the Lahore city ranges from 0.45 to $1.5 \mathrm{~m} / \mathrm{year}$, with an average of about $0.7 \mathrm{~m} /$ year. Excessive groundwater depletion is also being observed in the Lower and Central parts of the Bari Doab. There are other areas as well. Some of the emerging negative effects of groundwater depletion in water stressed areas are:

- $\quad$ Drying up of wells;

- $\quad$ Deterioration of groundwater quality; and

- Increasing pumping costs.

As the population is increasing, therefore domestic water use being on top priority is automatically increasing. This extra water usage in the domestic and industrial sectors had been compensated with the non-beneficial evaporation in the past (due to waterlogged conditions), and presently at the cost of negative groundwater balance in various areas of the country. At the same time there are areas where waterlogging is still an alive issue. Thus, there is dire need to look into the existing water management in the country, at basin, regional and local scale [3].

\section{Transboundary Water}

The term "transboundary water" refers to sources of water that are shared among multiple user groups, with diverse values and different needs associated with water use. In this way, water crosses boundaries - be they those of economic sectors, legal jurisdictions, or political interests. From sets of individual irrigators and environmental advocates, to urban versus rural uses, to nations that straddle international waterways, essentially, all freshwater is transboundary water, and is important to society at local, national, regional, and international scales. Transboundary water shares certain characteristics that make their management especially complicated.

\section{Surface Drainage from India}

There are four drains which are entering from India to Pakistan as the following:

- $\quad$ Hudiara Drain;

- $\quad$ Kasur Nala;

- $\quad$ Fazilka Drain; and

- Salemshah Drain.

According to the Section IV point 4 of IWT, Pakistan shall maintain its proportions of the drains mentioned above with capacities not less than the capacities on the effective date [2]. It is also mentioned in the treaty at Section IV point 10 that each partner declared its intention to prevent as far as practicable, undue pollution of the water of the Rivers. 


\section{Hudiara Drain}

Hudiara Drain is one of the most polluted tributaries of River Ravi nowadays. The drain originates near Gurdaspur district of Indian Punjab and enters Pakistan at Lallo Village after carrying the industrial and domestic effluent of Amritsar district. The total length of Hudiara Drain is about $98 \mathrm{~km}$ (from its starting point up to its discharging point in Ravi). The length of the drain in Pakistan is $55 \mathrm{~km}$. The drain is laden with a lot of heavy metals in India which are polluting not only the surface water of Pakistan but also Indian Punjab groundwater which ultimately comes to Pakistan through transboundary groundwater flow (Figure 2).

Figures 3 \& 4 show groundwater elevation on both sides of border, about 10 years back.

Figure 2: Layout of Hudiara Drain (Afzal S., et al., 2000).



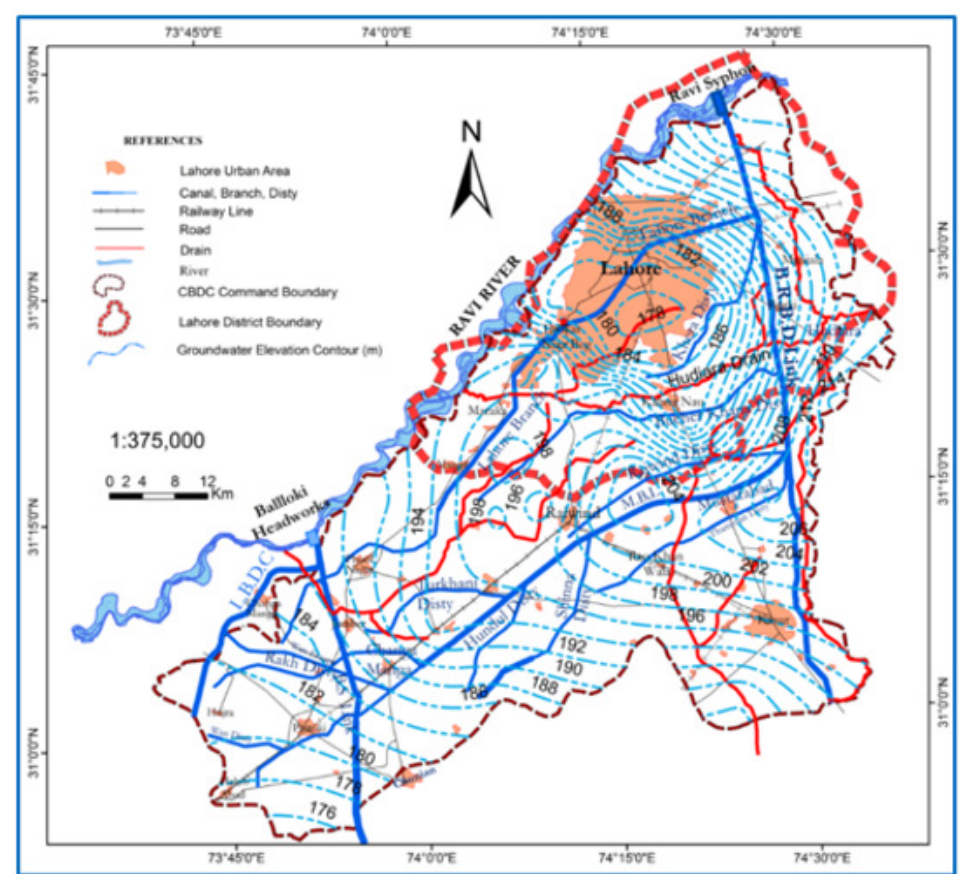

(3)

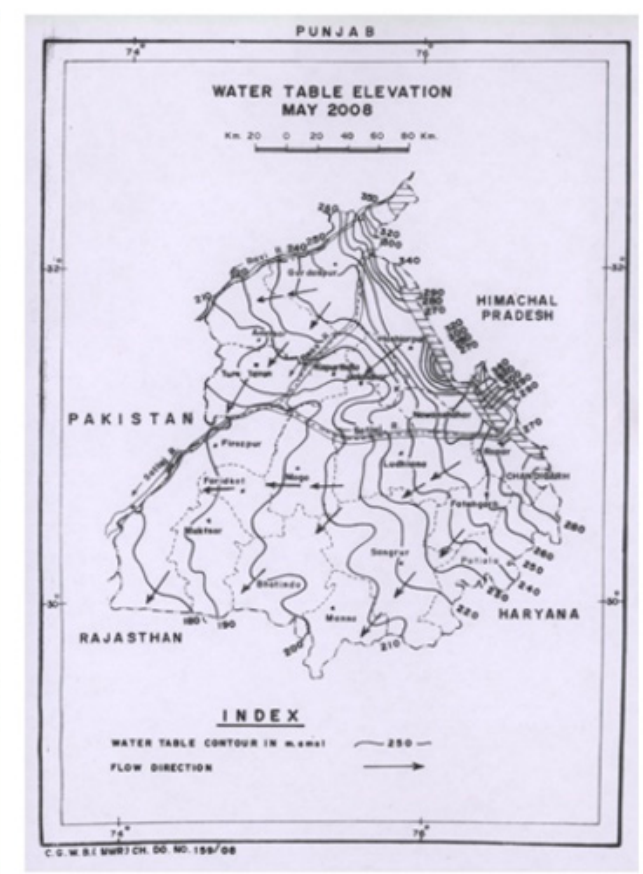

(4)

Figure 3: Groundwater Elevation Contours $(\mathrm{m})$ on Pakistani Side of Bari Doab (Basarat and Rizvi, 2011).

Figure 4: Groundwater Elevation Contours $(m)$ on Indian Side of Bari Doab (DK Chadha, 2016). 


\section{Hydrogeological Conditions of the Area}

During nineteen sixties, US Geological Survey initiated hydrogeological investigations in the Punjab, Pakistan, in cooperation with WAPDA under the auspices of the US Agency for International Development (USAID). The investigations included the drilling of test bores, construction of test tube wells, Study of the lithological logs of 149 test holes (600' to $1000^{\prime}$ depth) and 28 test tube wells (102' to 356' depth) indicates that Bari Doab consists of consolidated sand, silt and silty clay, with variable amounts of Kankers. The sands are principally grey or greyish-brown, fine to medium grained and subangular to sub rounded. Very fine sand is common, finer grained deposits generally include sandy silt, silt and silty clay with appreciable amounts of kanker and other concretionary materials [4]. In Bari doab area of Indian Punjab there are clay layers in aquifer. In Central Bari doab in Pakistani Punjab from Lahore to Okara clay layers are discontinuous and in lower Bari doab clay lay- ers are almost absent.

\section{Aquifer System of India}

Central Groundwater Board (CGWB) of India is mandated to carry out hydrogeological mapping aided with groundwater exploration, geophysical surveys, and evaluation of aquifer parameters, groundwater resource estimation and groundwater regime monitoring. Over the years, CGWB through its studies has created huge database in the form of water levels, water quality, sub-surface lithological \& geophysical logs and aquifer parameters. Analysis of the data base has enabled the preparation of hydrogeological maps including the groundwater management plans where the aquifer wise area suitable for groundwater recharge, development and conservation have been identified. Based on the hydrogeological characteristics, the entire country has been classified into 14 Principal Aquifer Systems and 42 major aquifers. Alluvium is the major aquifer system which covers maximum area of around 31\% [5].

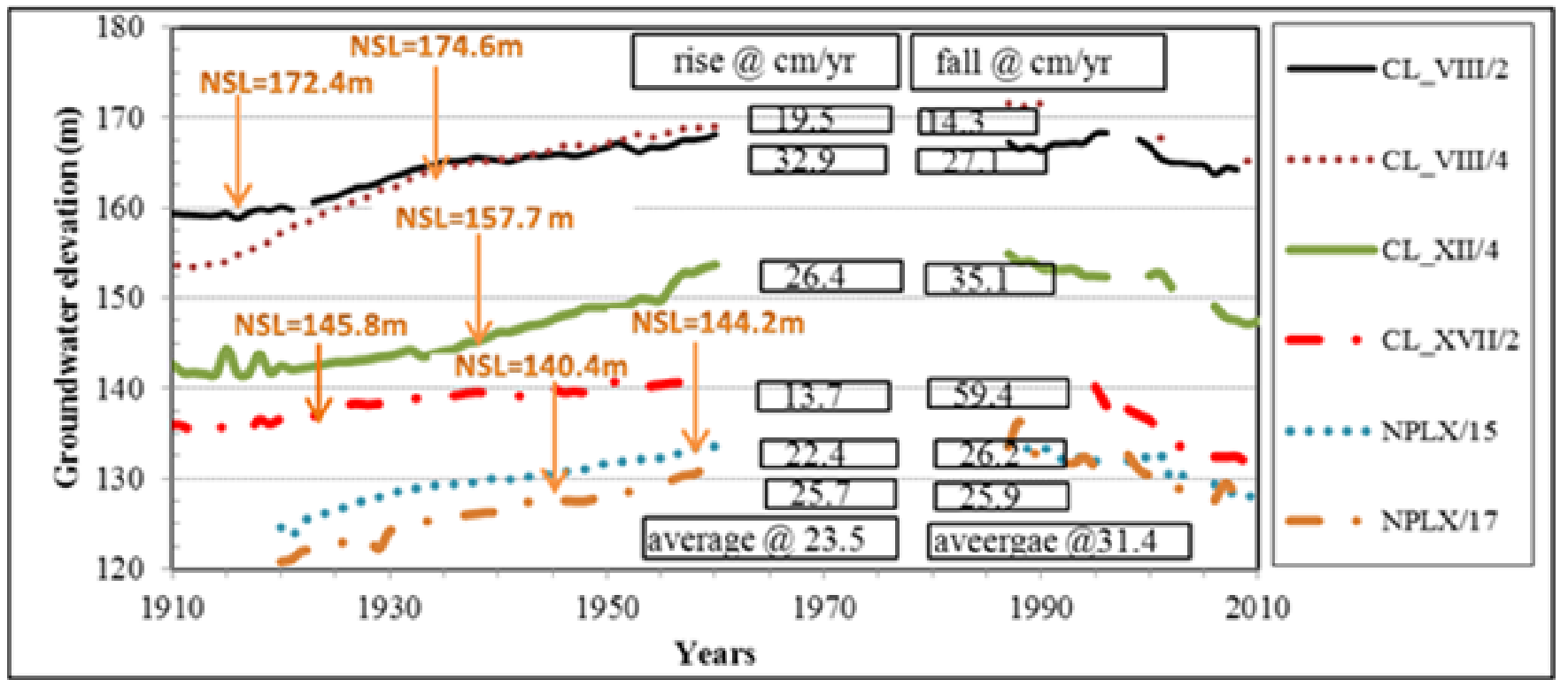

Figure 5: One Century Groundwater Levels, filling and depletion under LBDC Command (Basharat and Tariq, 2013).

Particularly, the lower and central parts of the Bari Doab are being excessively mined in groundwater. The changes in groundwater levels over the last century in LBDC command (middle of Bari Doab in Pakistan), in response to irrigation system inception (without groundwater irrigation) and then from the 1960s onward, groundwater pumping by farmers to supplement short irrigation supplies, are shown in Figure 5. The average rate of groundwater rise was $23.5 \mathrm{~cm} /$ year for these six observation wells. The period from 1987 to 2008 indicates a depletion rate of $31.4 \mathrm{~cm} /$ year, i.e. an even faster depletion than its aforementioned rise rate. The lower half of the LBDC canal command is facing an acute groundwater mining problem. Also, in the upper part of the Bari Doab (CBDC irrigation system), there are no signs of extraordinary groundwater depletion and this can be attributed to relatively more rainfall in these areas. Figures 5 \& 6 show DTW in Bari Doab, Punjab, Pakistan in Post-Monsoon 2010 \& 2014, respectively. The latest trends in groundwater levels at selected representative WASA tube wells for the years 2000 to 2014 is also shown in Figure 6.

Accordingly, minimum annual depletion rate is along the Ravi River i.e. in Shahdra, Krishan Nagar, Farrukhabad $(0.43 \mathrm{~m})$, then the areas of Data Nagar and Ravi road $(0.45 \mathrm{~m})$, Sabzazar and Shadbagh $0.57 \mathrm{~m}$ ), Baghbanpura, Samanabad, Johar Town 0.83m), Ichra, Township, Green Town, Garden Town (1.0m) and Gulberg, Mozang, Mughalpura, Mustafabad (1.08m). Overall average annual groundwater depletion is $0.78 \mathrm{~m}$ in WASA water supply area, whereas maximum depletion of $1.5 \mathrm{~m} /$ annum was found in the tube wells installed at Doungi Ground, Fazlia Colony of Mozang Sub-Divi- 
sion. Also, the maximum depth to groundwater was observed as 46.71m, in E-1 Block of Gulberg-III. Thus, the areas of Gulberg and Shah Jamal, along the Lahore Branch Canal have maximum depth to groundwater, or in other words the center of groundwater depression. In addition, over-exploitation of deeper groundwater is causing groundwater pollution due to leakage from shallow unconfined aquifers.

\section{Transboundary Aquifer Types}

Without considering the properties, especially land, groundwater management could not be complete. To account for these unique characteristics, transboundary groundwater management should utilize the three-dimensional approach, rather than the two-dimensional approach used for surface water. In the two-dimensional approach, scientists study the behavior of surface water on a single plane. With groundwater, water percolates into the soil, drawn by gravity. It moves along more than one plane. The three-dimensional approach takes into account this complexity of behavior.

It is hard to determine sovereignty for an aquifer with respect to the scale of both surface development and belowground struc- ture. However, four different cases can be used to determine sovereignty [6]:

Case 1: A State-owned aquifer, which is the entire aquifer in a State.

Case 2: $\quad$ A confined aquifer divided by an international boundary.

Case 3: In aquifer that is entirely in the territory of a State linked hydrologically with an international river.

Case 4: An aquifer that is entirely in the territory of one State but is hydrologically linked with another aquifer in a neighboring state.

These bests describe guidelines for classifying transboundary groundwater. Except for Case 1, these conditions address possible sharing of an aquifer between States. One modification of Case 2 should be noted: if there is a hydrological relationship where intra-State rivers/lakes are linked to an international aquifer, then it is important to be aware of this relationship because the intra-State rivers or lakes may have some influence on the aquifer [7].



Figure 6: Groundwater levels in Lahore City (2000 - 2014) (Basharat M., 2015).

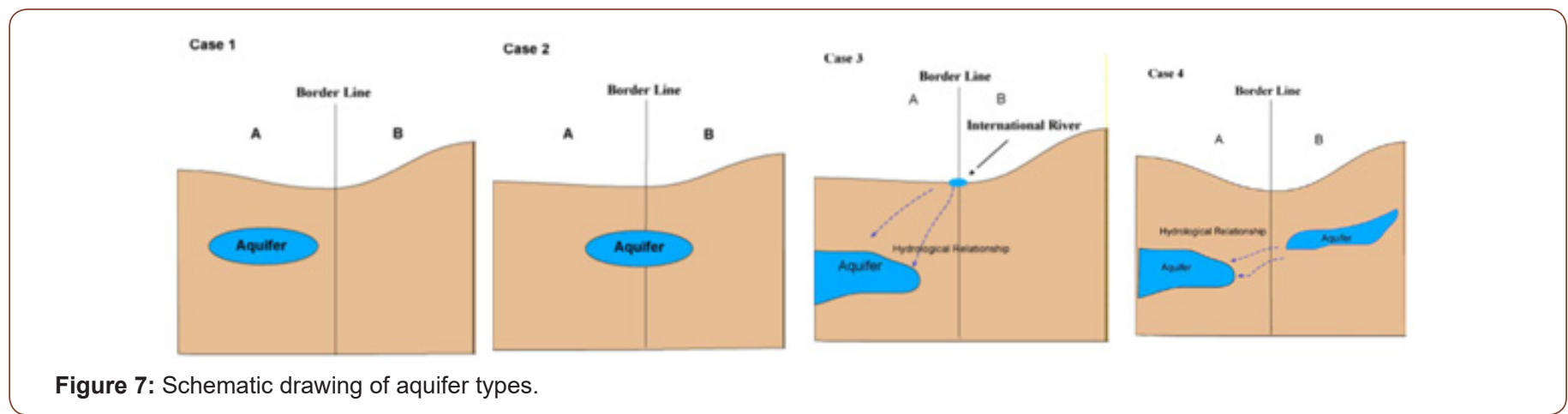

The aquifer system between India and Pakistan lies in case 2 out of the above given cases where the aquifers are shared and still unknown that water of both sides of boundary can move from one direction to the other depending upon the use and amount at one side of the aquifer (Figure 7). 
These guidelines suggest possible conditions that determine the transboundary nature of aquifers and provide a means by which States can proactively manage transboundary aquifers. In addition, these categories are important not only in defining the nature of the aquifer itself, but also in illustrating the scope of the hydrological relationships between aquifer-sharing States. Management with a transboundary element is extremely difficult because of the challenges of cooperation among neighboring countries. This can be an additional obstacle for transboundary aquifer management system.

\section{Evolution of International Groundwater Management in Environmental Law}

The principles for transboundary groundwater management have not yet been fully and visibly developed. The reasons for the absence of transboundary groundwater law are, as Krishina \& Salman [8] point out, "the inadequacy of scientific data" and "complexity of the issues of groundwater". In order to allow for uncertainty concerning the physical characteristics of groundwater, principles or laws on transboundary groundwater are left undefined or ambiguous. These ambiguities are discussed in real contexts in the Helsinki Rules, Seoul Rules, Bellagio Draft Treaty, Agenda 21, The Law of the Non-Navigational Use of International Watercourses, and the Convention on the Protection and Use of Transboundary Watercourses and International Lakes.

\section{Past Research Work on Water Pollution of Hudiara}

In Pakistan, annual per capita water availability was about 5260 $\mathrm{m}^{3}$ in 1951 , which had dropped to less than $1000 \mathrm{~m}^{3}$ by the year 2015 , a level commonly taken to indicate water scarcity. Whenever good quality water is scarce, water of marginal quality of drains has to be considered for use in agriculture [9]. Municipal wastewater also contained a variety of inorganic substances from domestic and industrial sources, including a number of potentially toxic elements such as cadmium, copper, lead, and zinc [10] and nutrients ( $\mathrm{N}$ and P) which are responsible for eutrophication of water bodies [11]. Even if major cations ( $\mathrm{Na}, \mathrm{Ca}, \mathrm{Mg})$, anions $\left(\mathrm{CO}_{3}, \mathrm{HCO}_{3}, \mathrm{Cl}\right.$, and $\left.\mathrm{SO}_{4}\right)$, and toxic materials are not present in concentrations likely to affect humans, they might well be at phytotoxic levels, which would limit their agricultural use to affect humans, they might well be at phytotoxic levels, which would limit their agricultural use $[12,13]$; however, from the point of view of health, a very important consideration in agriculture use of wastewater, the contaminants of greatest concern are the pathogenic micro- and macro-organisms (to affect humans, they might well be at phytotoxic levels, which would limit their agricultural use $[12,14]$.

Newspaper media (28th April 1998: Dawn, the Frontier Post, The News) reported that the Hudiara Drain was turned into toxic waste from India due to the mortality of cattle reported in the area. The owners of the cattle bathed them in the drain water. The drain falls into the Ravi, it also destroys the aquatic life of the river and made it extremely dangerous for public health. The Ravi River already had a great concentration of industrial and chemical wastes from factories in and around Shahdra. The press demanded that the government should constantly monitor the water of the Hudiara Drain to determine the concentration of toxic elements, as well as carry out a campaign to warn the people of the area against the danger of using the drain water. It was told by the people living near the Hudiara Drain that before 1970, a large variety of fish existed there. At present there is no fish life in the Hudiara Drain due to high amount of pollutants present in it.

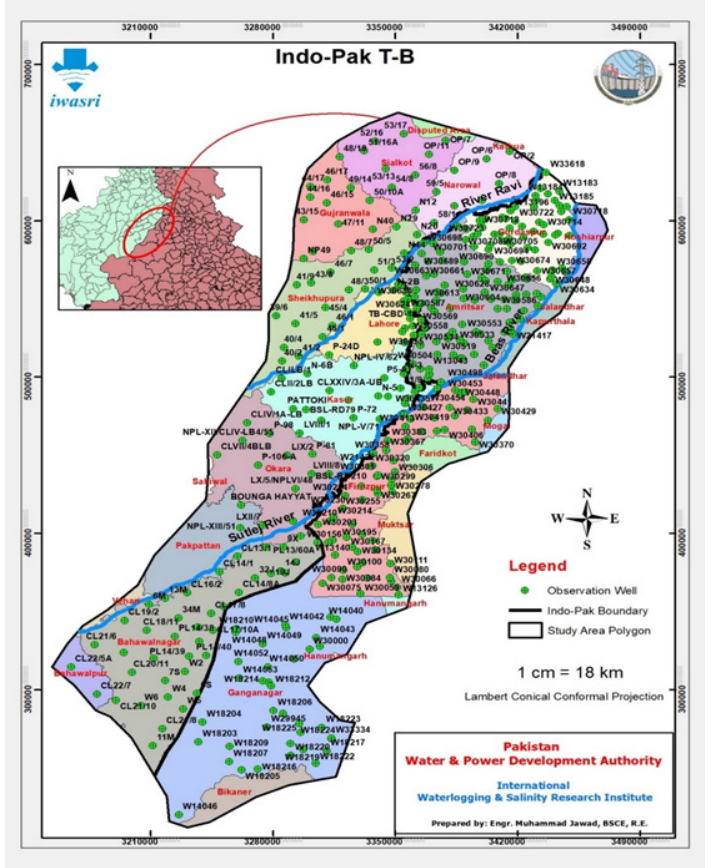

Figure 8: Observation points used for transboundary groundwater drainage. 


\section{Transboundary Groundwater Drainage}

For the determination of Transboundary groundwater flow the area of Bari Doab, Rechna Doab and Bahawalnagar area adjoining to Indian border were taken from Pakistani Side containing 138 observation wells. From Indian Side the districts of Indian Punjab i.e. Amritsar, Ferozpur, Gurdaspur and Tarn Taran and Ganganagar district from Rajasthan state were taken into consideration with total 243 observation wells data used for this study (as shown in Figure 8). The data of DTW from Indian side was taken from website of CGWB of India. The data used for both the countries was for the year 2017 post-monsoon. The total area of both sides is 57722.917 $\mathrm{km}^{2}$ overall.

\section{Hudiara Drain from India}

Hudiara Drain is the main surface drainage carrying channel which enters Pakistan near Lallo village at Indian border after passing through the main Industrial Hub of Indian, Punjab. As far as Hudiara Drain is concerned, its discharge and pollution both parameters were to be checked at regular intervals. The whole Hudiara Drain was selected for the study purpose. Total five gaging stations were selected where discharge measurement was carried out. In addition to Hudiara Drain, Satukatla Drain was also taking as a part of study area because it is the tributary of Hudiara Drain which throws the waste of Lahore area into Hudiara Drain.

\section{Discharge Measurement of Hudiara Drain}

The discharge measurement was carried out at five different gaging stations starting from the entrance of Hudiara Drain in the land of Pakistan near Lallo village up to end of the Drain at the point right after which the Drain discharges its water in Ravi River. The drain is an unlined channel, so the water also percolates into soil suspected to pollute groundwater underneath. The discharge measurement was carried out using the Velocity-Area method. The area was calculated by taking depth of water at different sections after regular intervals starting from a fixed reference.

Velocity of flow was measured using current meter method at each interval as discussed above. All the discharge measurement activities were carried out by ISRIP, WAPDA during different flow periods. The method for velocity measurement adopted was $0.6 \mathrm{~d}$ method, where $d$ is the depth of water from bed at the measuring section.

\section{Results and Discussions}

The groundwater data was collected from both the countries i.e. SCARPs Monitoring Organization (SMO) and Central Groundwater Board (CGWB), from Pakistan and India, respectively. The data was then processed on GIS for generation of elevation contours and profile development. The coordinate system used for the projection of layers was Lambert Conical Conformal Projection system with Datum taken as Kalyanpur India Zone-I. The discrete data points were interpolated using ordinary Kriging method, taking six points search radius set as an interpolation method. Semiveriogram model set for this project was spherical. The contour interval for the contour's development was taken as $3 \mathrm{~m}$. All the elevations were taken from MSL. The reference to these elevations is Google Earth, for both sides of the border as the error involved in the values was found same everywhere in the study area.

Once the contours were generated, critical sections along the Indo-Pak border in the selected study area were searched out for steepest gradient. After marking the sections flow along these flow lines was calculated using Darcy's law of groundwater movement. The Figure 9 show study area with elevation contours.

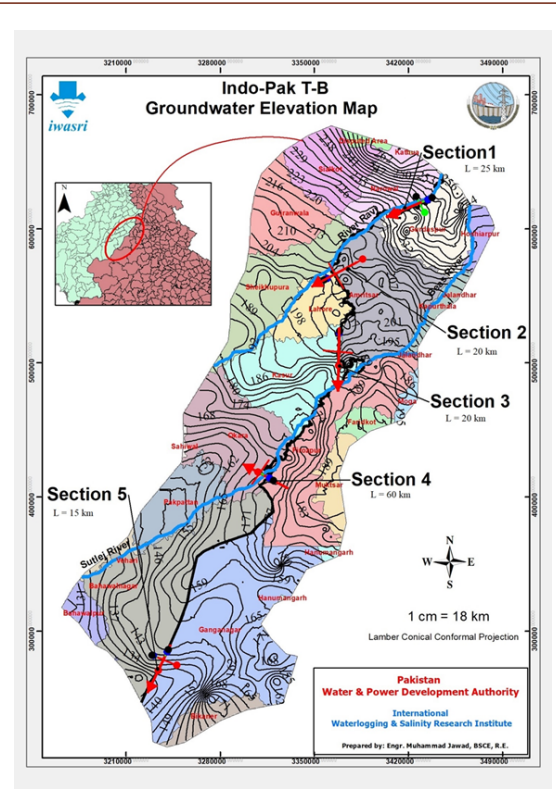

Figure 9: Indo-Pak Transboundary Groundwater Elevation Map across the border in Punjab. 


\section{Groundwater Drainage Quantum Computation}

The groundwater flow was calculated using Darcy's law. Assumptions were made for Steady state condition of groundwater flow. Darcy's law states that: the velocity of flow of a liquid through a porous medium due to difference in pressure is proportional to the pressure gradient in the direction of flow.

The flow of water is described as:

$$
Q=K \cdot A \cdot\left(\frac{h p-h Q}{L}\right)
$$

The coefficient ' $\mathrm{K}$ ' has dimensions of $\mathrm{L} / \mathrm{T}$, or velocity, and this is termed as the hydraulic conductivity.

The case above is described basically for flow of groundwater in confined aquifer. But the actual case of this study is unconfined aquifer everywhere in the study area along Indo-Pak border. For that there was considered no recharge of water from top, the flow takes place in the direction of fall of the hydraulic head, $h$, which is a function of the coordinate, $x$ taken in the flow direction The groundwater flow velocity, v, is governed by Darcy's law. Hence v is also a function of $x$ and increases in the direction of flow. Since, $v$, according to Darcy's law is shown to be

$$
V=K \cdot \frac{d h}{d x}(1)
$$

This was the equation used for calculation of groundwater flow at the five sections of the study area as marked in Figure 9. For the purpose of flow computation profile sections were plotted of saturated depth elevation of groundwater along with aquifer bed elevation, as shown in Figure 10, for section 2.

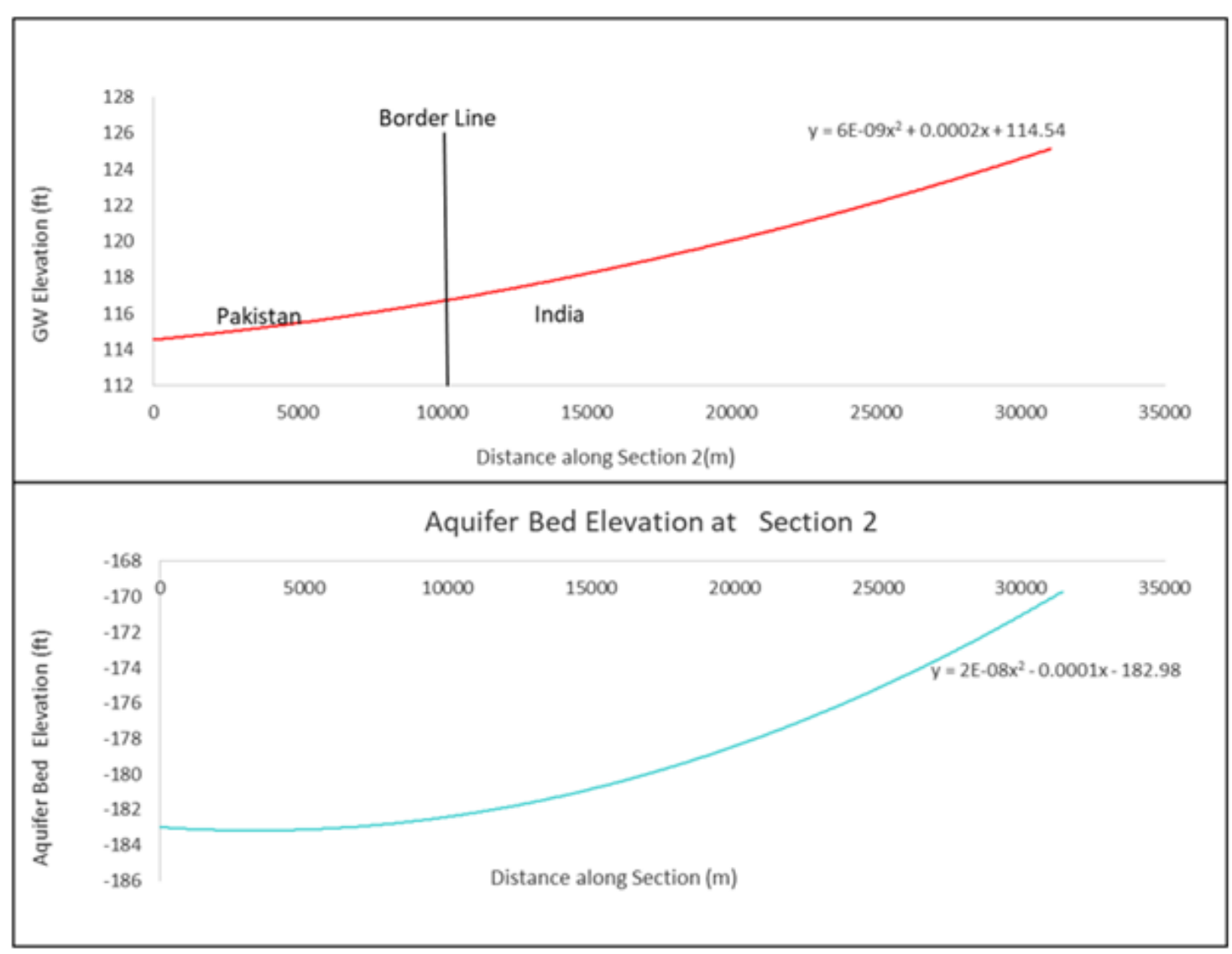

Figure 10: Groundwater elevation with Aquifer bed Elevation at Section 2.

\section{Dupuit Simplification}

This problem to calculate groundwater flow was solved and elaborated by J. Dupuit, a French hydraulician, and published in 1863 and his assumptions for a flow in an unconfined aquifer is used to approximate the flow situation called Dupuit flow. The assumptions made by Dupuit are:

- The hydraulic gradient is equal to the slope of the water table
- $\quad$ For small water table gradients, flowlines are horizontal \& equipotential lines are vertical.

There is another assumption which was made during the flow computation (as shown in Table 1) for this paper particularly is that, there is no seepage from the top of the ground or the other way around the system was considered as an isolated. The flow was considered one dimensional solely. 
Table 1: Groundwater Flow Quantum Computations Table.

\begin{tabular}{|c|c|c|c|c|c|c|c|c|c|c|c|c|}
\hline \multirow[b]{2}{*}{$\begin{array}{l}\text { Section } \\
\text { No. }\end{array}$} & \multirow[b]{2}{*}{$\begin{array}{c}\text { Section } \\
\text { Length } \\
(\mathrm{km})\end{array}$} & \multicolumn{2}{|c|}{$\begin{array}{c}\text { Profile Equation w.r.t. } \\
\text { MSL }\end{array}$} & \multicolumn{2}{|c|}{ Sq. (Head Difference) } & \multicolumn{3}{|c|}{ Unit Discharge (cum/day) } & \multirow{2}{*}{$\begin{array}{c}\text { Rep- } \\
\text { resen- } \\
\text { tative } \\
\text { Width } \\
\text { (W) at } \\
\text { Sec- } \\
\text { tion } \\
\text { (m) }\end{array}$} & \multirow{2}{*}{$\begin{array}{l}\text { Q for repre- } \\
\text { sent-tative } \\
\text { width at } \\
\text { designated } \\
\text { Section Q } \\
=\text { q X W } \\
\text { (cum/day) }\end{array}$} & \multirow[b]{2}{*}{$\begin{array}{l}\text { TB Flow } \\
\text { Q (cum/ } \\
\text { day) }\end{array}$} & \multirow[b]{2}{*}{$\begin{array}{c}\text { Re- } \\
\text { marks }\end{array}$} \\
\hline & & $\begin{array}{l}\text { GW Eleva- } \\
\text { tion }\end{array}$ & $\begin{array}{l}\text { Aquifer } \\
\text { Depth } \\
\text { Elevation }\end{array}$ & $\begin{array}{c}\text { GE } \\
\text { Elevation } \\
\mathbf{h}_{\mathrm{B}}{ }^{2} \mathbf{h}_{\mathrm{A}}{ }^{2}\end{array}$ & $\begin{array}{c}\text { Aquifer } \\
\text { Bed Ele- } \\
\text { vation } h_{B}{ }^{2} \\
-^{2}{ }^{2}\end{array}$ & $\begin{array}{l}\text { MSL to } \\
\text { GW Ele- } \\
\text { vation }\end{array}$ & $\begin{array}{l}\text { MSL to } \\
\text { Lowest } \\
\text { Aquifer } \\
\text { Bed } \\
\text { Eleva- } \\
\text { tion }\end{array}$ & $\begin{array}{l}\text { q(comm.) } \\
\text { (cum/ } \\
\text { day) }\end{array}$ & & & & \\
\hline 1 & 25 & $\begin{array}{c}\mathrm{h}=\mathrm{y}= \\
-0.0007 \mathrm{x}+ \\
251.98\end{array}$ & $\begin{array}{c}\mathrm{h}=\mathrm{y}= \\
-0.0006 \mathrm{x}- \\
143.95\end{array}$ & 14076.3 & 225 & 7.31967 & 0.117 & 7.202676 & 10000 & 72026.76 & 0 & $\begin{array}{l}\text { Along } \\
\text { Bound- } \\
\text { ary (NE } \\
\text { to SW) }\end{array}$ \\
\hline 2 & 20 & $\begin{array}{c}\mathrm{h}=\mathrm{y}= \\
6 \mathrm{E}-09 \mathrm{x}^{2}+ \\
0.0002 \mathrm{x}+ \\
114.54\end{array}$ & $\begin{array}{c}\mathrm{h}=\mathrm{y}= \\
2 \mathrm{E}-08 \mathrm{x}^{2} \\
-0.0001 \mathrm{x} \\
-182.98\end{array}$ & 3849.216 & 36 & 2.50199 & 0.0234 & 2.4785904 & 10000 & 24785.904 & 24785.904 & $\begin{array}{l}\text { To- } \\
\text { wards } \\
\text { (Paki- } \\
\text { stan) }\end{array}$ \\
\hline 3 & 20 & $\begin{array}{c}\mathrm{h}=\mathrm{y}= \\
-2 \mathrm{E}-08 \mathrm{x}^{2}- \\
6 \mathrm{E}-05 \mathrm{x}+ \\
204.68\end{array}$ & $\begin{array}{c}\mathrm{h}=\mathrm{y}= \\
-0.0004 \mathrm{x}- \\
187.66\end{array}$ & 7281.616 & 64 & 4.73305 & 0.0416 & 4.6914504 & 10000 & 46914.504 & 0 & $\begin{array}{l}\text { Along } \\
\text { Bound- } \\
\text { ary (N } \\
\text { to } S \text { ) }\end{array}$ \\
\hline 4 & 60 & $\begin{array}{c}\mathrm{h}=\mathrm{y}= \\
-0.0002 \mathrm{x}+ \\
169.78\end{array}$ & $\begin{array}{c}\mathrm{h}=\mathrm{y}= \\
3 \mathrm{E}-08 \mathrm{x}^{2}+ \\
0.0006 \mathrm{x}- \\
221.24\end{array}$ & 1524.08 & 0 & 1.9813 & 0 & 1.981304 & 10000 & 19813.04 & 19813.04 & $\begin{array}{l}\text { To- } \\
\text { wards } \\
\text { (Paki- } \\
\text { stan) }\end{array}$ \\
\hline 5 & 15 & $\begin{array}{c}\mathrm{h}=\mathrm{y}= \\
-9 \mathrm{E}-09 \mathrm{x}^{2}- \\
0.0007 \mathrm{x}+ \\
152.3\end{array}$ & $\begin{array}{c}\mathrm{h}=\mathrm{y}= \\
-0.0004 \mathrm{x}- \\
243.45\end{array}$ & 9906.962 & 36 & 8.58603 & 0.0312 & 8.5548337 & 10000 & 85548.3373 & 0 & $\begin{array}{l}\text { Along } \\
\text { Bound- } \\
\text { ary (NE } \\
\text { to SW) }\end{array}$ \\
\hline
\end{tabular}

The unit discharge can be calculated as:

$$
q=V \cdot A
$$

The treaty resulted in partitioning of the rivers rather than sharing of their water (Grag and Kumar, 2010). Once below Madhupur headworks, water being at very low level and Ravi River is dried below Madhupur, the groundwater recharge in this affected area is significantly reduced, causing an obvious elevation head difference across the border. This is the cause which renders the gradient direction towards Pakistan in area adjoining to Ravi River. Moreover, high rate of groundwater pumping in Lahore is also the cause. Using these groundwater elevation and aquifer bed profiles w.r.t. Mean Sea Level (MSL) and following Dupuit equation, flow tables were prepared. At every section the width of section was taken as $10 \mathrm{~km}$ for the representation of the whole area. The results show that at Section 1, 3 and 5 the flow of groundwater is along border line and across the border there is no flow theoretically either side of the border line. The results also indicate that in these areas the Transboundary groundwater is in equilibrium and is flowing NE to SW direction.

Section 2 and 4 indicate that gradient of groundwater flow is towards Pakistan. The location of Section 2 is just parallel to Ravi River. On the Ravi River, the earliest project built was the Madhopur Headworks, in 1902. It is a run-of-the river project (no storage was envisaged) to divert flows through the Bari Doab Canal to provide irrigation in the command area of the then unified India and Pakistan.
Similarly, the case of Section 4 is very much similar to Section 2, where the River Sutlej facing the problem of low flows. In 1953 India constructed Harike Headworks on Sutlej River at the confluence of Beas and Sutlej River and stopped the water from entering Pakistan right after its construction. After IWT in 1960, very low water is being released below Ferozpur Headworks which is causing similar type of groundwater elevation gradient from India to $\mathrm{Pa}$ kistan. Hence it can be inferred from the Figure 9, that in the area of Section 2 and Section 4 the groundwater elevation gradient is also a function of seepage quantum from the bed of Ravi and Sutlej Rivers, respectively. In total $0.0132 \mathrm{MAF}$ groundwater is flowing towards Pakistan annually at section 2 and section 4 (cumulative).

\section{Conclusion and Recommendations}

\section{Conclusion}

Following are the conclusions drawn from this research:

- IWT 1960, involved only the surface water of Indian Sub-Continent and their distribution. However, the recharge of Groundwater is an important parameter which is the function of surface water flow and neglected in the treaty of IWT, 1960 [2].

- It was found that, throughout the Indo-Pakistan border there is no such section where there was gradient of groundwater flow towards India. Rather, at two critical sections i.e. at section 2 and Section 4, the flow gradient is towards Pakistan. As a result, 0.0132 MAF/annum water is moving from India to Pakistan, where the groundwater elevation in India being at higher level than Pakistan. 
- Moreover, increased pumping trends in Pakistan, mostly in Bari Doab area, also adding to it. In the other critical sections along Indo-Pak border the flow of groundwater is along the border following NE to SW direction at some places and $\mathrm{N}$ to $\mathrm{S}$ in other areas. Groundwater mining in Indian Punjab and Rajasthan areas is away from border, which is the effect of high rate of groundwater pumping in the populated areas for domestic and agricultural purposes.

- There are four eastern drains entering from Indian side, as mentioned in IWT. Out of all these drains Hudiara Drain carries more pollutants. A study was carried out on the pollution of Hudiara by Afzal S. et al. [11]. The results showed that COD, BOD and TSS were not in the permissible limits as defined by NEQS.

- In total the average annual volume of drainage effluent entering from Indian side to Pakistan in Hudiara Drain was calculated as 0.13 MAF/year containing $354 \mathrm{ppm}$ Total Suspended Solids in drain water which becomes $57416 \mathrm{Mg} /$ year.

- After entering in Pakistan, a lot of small drains and one major drain i.e. Satukatla Drain outfalls in Hudiara Drain, unless Hudiara Drain discharges its water in Ravi River amounting to average volume of $0.36 \mathrm{MAF} /$ year. The water of Hudiara mixes with Ravi River water which is then used for irrigation purpose through irrigation canals in area of Bari Doab [15-17].

\section{Recommendations}

Following are the recommendations of this paper regarding Transboundary groundwater drainage from India.

- Minimum water should be released in the eastern rivers i.e. in the Ravi, the Beas and the Sutlej, also called environmental flows round the year in order to recharge aquifer underneath to minimize the groundwater depletion in Bari Doab area which is not mentioned in IWT.

- $\quad$ National Water Policy of Pakistan, March-2018 recently approved by Government of Pakistan should be strictly implemented

- India must release its industrial00 and domestic effluent in Hudiara Drain and all other three drains after treatment, so that it may neither contaminate groundwater of Pakistan nor it disturbs the Environment related parameters.

\section{Compliance with Ethical Standards}

To ensure objectivity and transparency in research and to ensure that accepted principles of ethical and professional conduct have been followed. No Conflict of interests were involved. Study support was provided by the Ministry of Water Resources. Some or all data or code generated or used during the study are available in a repository in accordance with funder data retention policies.

\section{Acknowledgement}

None.

\section{Conflict of Interest}

No conflict of interest

\section{References}

1. Rodell M, Velicogna I, Famiglietti JS (2009) Satellite-based estimates of groundwater depletion in India. Nature 460(7258): 999.

2. Indus Water Treaty (1960) Site Resources; World Bank. pp. 1-24.

3. Basharat M (2015) Groundwater Environment and Evaluation of Long-Term Sustainability of the Aquifer Under Lahore. Presented at World Water Day, organized by Pakistan Engineering Congress at its headquarters in Lahore, Pakistan.

4. Greenman DW, Swarzenski WV, Bennett GD (1967) Ground-water hydrology of the Punjab, West Pakistan, with emphasis on problems caused by canal irrigation. US Government Printing Office.

5. CGWB (2012) Aquifers Systems of India, Published Report by Central Ground Water Board India, Ministry of Water Resources, India.

6. Barberis Julio (1991) The development of international law on transboudary groundwater. Natural Resource journal 31: 167-188:

7. Matsumoto Kyoko (2002) Transboundary Groundwater and International Law: Past Practices and Current Implications. Oregon State University. Master's paper.

8. Krishna R, Salman SM (1999) International groundwater law and the World Bank policy for projects on transboundary groundwater. World Bank Technical Paper, 163-190.

9. Asrar-ul-Haq, Sufi BA, Shakir AS (1997) Indus Basin water resources: sustainability concerns and optimization strategies, edited by: Tariq AR, Latif M, Water for the 21st Century: Demand, Supply, Development and Socio-environmental Issues. In Proceedings of an International Symposium, Centre of Excellence in Water Resources Engineering Publications, Lahore 110: 61-76.

10. Younas M, Shahzad F, Afzal S, Khan MI, Ali K (1998) Assessment of Cd, $\mathrm{Ni}, \mathrm{Cu}$, and $\mathrm{Pb}$ pollution in Lahore, Pakistan. Environment International 24(7): 761-766

11. Afzal S, Ahmad I, Younas M, Zahid MD, Khan MA, et al. (2000) Study of water quality of Hudiara drain, India-Pakistan. Environment International 26(1-2): 87-96.

12. Ayers RS, Westcot DW (1989) Water Quality for Agriculture. FAO Irrigation and Drainage 29(1), Rome.

13. Pescod MB (1992) The urban water cycle, including wastewater use in agriculture. Outlook on agriculture 21(4): 263-270.

14. Pescod MB (1992a) Wastewater treatment and use in agriculture.

15. Basharat M, Tariq AR (2013) Spatial climatic variability and its impact on irrigated hydrology in a canal command. Arabian Journal for Science and Engineering. 38(3): 507-522.

16. Basharat M, Rizvi SA (2011) Groundwater Extraction and Wastewater Disposal Regulation - Is Lahore Aquifer at Stake with as Usual Approach? World Water Day April-2011.

17. Garg and Kumar S (1999) International and interstate river water disputes. Laxmi Publications. pp. 54-55. 